\title{
Mycorrhizal fungi increase coffee plants competitiveness against Bidens pilosa interference ${ }^{1}$
}

\author{
André Cabral França ${ }^{2}$, Ana Flávia de Freitas ${ }^{2}$, \\ Edson Aparecido dos Santos ${ }^{2}$, Paulo Henrique Grazziotti ${ }^{2}$, Valter Carvalho de Andrade Júnior ${ }^{2}$
}

\begin{abstract}
Mycorrhizae provide several benefits to coffee plants. This study evaluated whether these benefits influence the damage caused by the Bidens pilosa competition with coffee seedlings. A randomized blocks design was used, with treatments established in a 2 × 3 factorial scheme (presence and absence of B. pilosa interference in non-inoculated control or plants inoculated with either Claroideoglomus etunicatum or Dentiscutata heterogama). Coffee seedlings were inoculated with fungi spores and developed for 120 days. Then, they were subjected to the interference of $B$. pilosa for more 120 days, when data were collected for growth traits, mycorrhizal colonization, dry matter and foliar nutrient concentrations in coffee plants. Dry matter and nutrient contents in B. pilosa plants were also evaluated. Inoculation provided better growth and nutrition of coffee plants. The competition with $B$. pilosa reduced mycorrhizal colonization, height, leaf area, leaf and stem dry mass, root dry weight, number of reproductive branches and levels of $\mathrm{P}$ and $\mathrm{Fe}$ in the coffee plants. However, the harmful effect of the interference was lower in inoculated coffee plants. The dry mass of $B$. pilosa decreased under the interference of inoculated coffee plants. The inoculation of $C$. etunicatum and D. heterogama in Arabica coffee seedlings increases the competitiveness of the crop against $B$. pilosa interference.
\end{abstract}

KEY-WORDS: Claroideoglomus etunicatum; Coffea arabica L.; Dentiscutata heterogama.

\section{INTRODUCTION}

Like all crops, coffee plants (Coffea arabica L.) are affected by the negative effects of weeds. The damage occurs mainly by competition for soil resources, particularly nutrients and water. The interference becomes even more damaging when plants are in the early stages of development, when weeds are more efficient in using resources (Ronchi \& Silva 2006).

\section{RESUMO}

Fungos micorrízicos aumentam a competitividade de cafeeiro frente à interferência de Bidens pilosa

As micorrizas proporcionam diversos benefícios às plantas de cafeeiro. Avaliou-se se esses benefícios influenciam nos danos causados pela competição de Bidens pilosa com plantas jovens de café. Utilizou-se delineamento em blocos casualizados, com tratamentos estabelecidos pelo fatorial $2 \times 3$ (presença e ausência da interferência de B. pilosa em plantas inoculadas com Claroideoglomus etunicatum ou Dentiscutata heterogama e não inoculadas). Plântulas de café foram inoculadas com esporos dos fungos e se desenvolveram por 120 dias. Em seguida, foram submetidas à interferência de B. pilosa por mais 120 dias, quando foram coletados dados de crescimento, colonização micorrízica, massa seca e teores foliares de nutrientes no cafeeiro. Também foram avaliados a massa seca e os teores de nutrientes em plantas de $B$. pilosa. A inoculação proporcionou melhor crescimento e nutrição das plantas de café. A competição com B. pilosa reduziu a colonização micorrízica, altura, área foliar, massa seca de folhas e de caule, massa seca de raízes, número de ramos plagiotrópicos e teores de $\mathrm{Pe} F$ e das plantas de café, porém, esse efeito foi menor nas plantas inoculadas. A massa seca de B. pilosa diminuiu sob a interferência de plantas de café inoculadas. A inoculação de $C$. etunicatum e $D$. heterogama, em mudas de café arábica, aumenta a capacidade competitiva da cultura frente à interferência de B. pilosa.

PALAVRAS-CHAVE: Claroideoglomus etunicatum; Coffea arabica L.; Dentiscutata heterogama.

Weed interference in crops of economic interest is one of the major plant defense problems (Oerke 2006). Among various weed species, blackjack biotypes (Bidens pilosa L.), in some cases, are classified as the most important ones in coffee plantations, due to the fast initial growth and efficient use of environmental resources, especially nutrients and water (Ronchi et al. 2007, Santos \& Cury 2011).

Herbicides are the main control method for weed management in coffee plantations, in Brazil.

1. Manuscript received in Jan./2016 and accepted for publication in May./2016 (http://dx.doi.org/10.1590/1983-40632016v4639485).

2. Universidade Federal dos Vales do Jequitinhonha e Mucuri, Campus JK, Diamantina, MG, Brazil.

E-mails: cabralfranca@yahoo.com.br,ninhadtna13@hotmail.com, edsonapsant@yahoo.com.br, grazziot@yahoo.com.br, valterjr@ufvjm.edu.br. 
However, it is much recommended and widespread among producers the integrated weed control, whereby the chemical method is integrated with one or more techniques that favor the development of coffee plants.

Higher growth rates make coffee plants more competitive and less affected by weed interference. By diminishing herbicide application, the integrated weed control aids on the sustainability of the agricultural systems (Harker \& O'donovan 2013).

Coffee plants have an intimate relationship with soil microorganisms, especially with arbuscular mycorrhizal fungi (AMF). AMF are responsible for increasing seedling growth (França et al. 2014), better water and nutrient absorption (especially low solubility ones), and tolerance to adverse environmental factors (Smith \& Smith 2012). However, in the conventional seedling production, plants are not inoculated with $\mathrm{AMF}$, and natural colonization is slow. Because of that, many researchers have reported evident increases in seedling growth after the artificial inoculation with AMF spores, especially from the Claroideoglomus and Dentiscutata groups (Pagano et al. 2010, Trejo et al. 2011, Ferrazzano \& Williamson 2013, Carvalho et al. 2014).

Interactions between AMF inoculations in crops with competition by weeds have already been demonstrated by Veiga et al. (2011). According to these authors, the artificial inoculation of AMF on maize and wheat is beneficial not only because it provides better nutrition to crops, but also because it decreases the biomass accumulation of the weeds Echinocloa crus-galli, Setaria viridis and Solanum nigrum. In addition, some AMF species are parasites of many weeds considered highly aggressive (Rinaudo et al. 2010).

Thus, in a situation of competition between coffee seedlings and B. pilosa, the artificial inoculation with AMF can be beneficial, because it can provide better crop development, helping the proper weed management. Therefore, this study aimed at evaluating the growth and nutrient content of young coffee plants inoculated with AMF and submitted to competition with B. pilosa.

\section{MATERIAL AND METHODS}

The experiment was conducted in a greenhouse, from November 2013 to June 2014. The treatments were established by a 2 × 3 factorial scheme, where the first factor consisted of coffee plants grown with and without the interference of B. pilosa and the second of coffee inoculation with Claroideoglomus etunicatum, Dentiscutata heterogama or a noninoculated control. A randomized blocks design, with four replications, was used.

Coffee seeds (Coffea arabica L.; Catuaí Vermelho IAC 99 cultivar) were selected and germinated in washed sand, where the seedlings developed to the "matchstick" stage. After that, they were transferred to polyethylene bags with $1.6 \mathrm{dm}^{3}$ of a non-sterilized Red-Yellow Latosol. The soil was previously sieved (4 $\mathrm{mm}$ mesh) and physicochemically characterized (Table 1).

At the time of the transference to the bags, the seedlings of the inoculated treatments received on the roots either $9.1 \mathrm{~g}$ of the inoculum Dentiscutata heterogama (TH Nicolson \& Gerd.) (PNB102A) or $7.14 \mathrm{~g}$ of Claroideoglomus etunicatum (Becker \& Gerdemann) (RJN101A) Walker \& Schüssler. This amount was sufficient to provide 100 spores of each fungus per seedling, as determined by the protocol proposed by Gerdemann \& Nicholson (1963). In addition to spores, the inoculum consisted of sand, expanded clay and fragmented roots, and they were obtained from the Coleção Internacional de Culturas de Glomeromycota (CICG), in Blumenau, Santa Catarina State, Brazil. Non-inoculated plants did not receive any type of inoculant.

Table 1. Characterization of the dystrophic Red-Yellow Latosol used for the cultivation of coffee seedlings.

\begin{tabular}{|c|c|c|c|c|c|c|c|c|c|}
\hline \multirow{2}{*}{$\begin{array}{c}\mathrm{pH} \\
\left(\mathrm{H}_{2} \mathrm{O}\right)\end{array}$} & $\mathrm{P}$ & K & $\mathrm{Ca}^{2+}$ & $\mathrm{Mg}^{2+}$ & $\mathrm{Al}^{3+}$ & $\mathrm{H}+\mathrm{Al}$ & $\mathrm{T}$ & $\mathrm{t}$ & OM \\
\hline & \multicolumn{2}{|c|}{$\mathrm{mg} \mathrm{dm}^{-3}$} & \multicolumn{6}{|c|}{$\mathrm{cmol}_{\mathrm{c}} \mathrm{dm}^{-3}$} & dag $\mathrm{kg}^{-1}$ \\
\hline 4.9 & 1.3 & 8.0 & 0.1 & 0.1 & 0.3 & 46 & 4.9 & 0.6 & 1.9 \\
\hline P-rem & $\mathrm{Zn}$ & $\mathrm{Fe}$ & $\mathrm{Mn}$ & $\mathrm{Cu}$ & $\mathrm{B}$ & & sand & silt & clay \\
\hline $\mathrm{mg} \mathrm{L}^{-1}$ & & & $\mathrm{gg} \mathrm{dm}$ & & & & - & 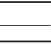 & \\
\hline 7.1 & 0.2 & 30.5 & 0.7 & 0.1 & 0.1 & & 38 & 8 & 56 \\
\hline
\end{tabular}

OM: organic matter; SB: sum of bases; t: effective cation exchange capacity; T: cation exchange capacity at pH 7.0; m: aluminum saturation; V: base saturation. 
At 115 days after the transplant of coffee seedlings, $B$. pilosa seeds were placed separately to germinate in washed sand. After 120 days, coffee seedlings with six pairs of developed leaves were transferred to pots with $20.0 \mathrm{~L}$ of the same soil previously described, fertilized with $450 \mathrm{~g} \mathrm{~m}^{-3}$ of $\mathrm{P}$, $500 \mathrm{~g} \mathrm{~m}^{-3}$ of K and $30 \mathrm{~g} \mathrm{~m}^{-3}$ of N. Half of these plants was subjected to the interference of two B. pilosa seedlings, $3.0 \mathrm{~cm}$ height, at the first true leaf stage. B. pilosa plants were placed $10 \mathrm{~cm}$ apart from the coffee plant, in opposite cardinal positions. At 30 and 60 days, additional fertilizations with nitrogen were carried out $\left(35 \mathrm{~g} \mathrm{~m}^{-3}\right)$.

After 60 days of competition, B. pilosa plants began the flowering process and were cut close to the ground and discarded. One budding of each plant was maintained for more 60 days, for evaluations.

After 120 days of growth in pots of $20 \mathrm{~L}$, coffee plants height, leaf area and number of reproductive branches were determined (Antunes et al. 2008). Then, the plants were cut close to the ground, separated into leaves and stems and dried for 72 hours, at $65^{\circ} \mathrm{C}$, for evaluating dry weight. Roots were washed with tap water until the total elimination of soil. Root length and percentage of colonized length were determined (Giovannetti \& Mosse 1980), as well as roots dry weight.

The dried leaves of coffee seedlings were ground in a mill (Willey) for estimating the contents of P (Braga \& De Fellipo 1974), K, Ca, Mg, Cu, Mn, Fe and Zn (AOAC 1975). In addition, the B. pilosa plants were also subjected to the same procedures for determining the dry matter and foliar nutrients contents, in the pre-flowering stage.

Treatments were compared with analysis of variance and the levels of significant factors were compared by the Tukey test, at $5 \%$. Moreover, for better visualization, growth and inoculated coffee biomass data were compared with those from plants under interference, using the effect of percentage compared to the control.

\section{RESULTS AND DISCUSSION}

The analysis of variance $(\mathrm{p}<0.05)$ detected the significance of the $B$. pilosa competition, AMF inoculation and the interaction between them for all growth variables and biomass accumulation in coffee plants. The exception occurred for the stem and leave dry mass, in which only the effect of the $B$. pilosa competition was significant. The effect of mycorrhizal colonization was significant for the coffee roots and biomass, as well as for the nutrient contents in B. pilosa plants. Finally, there was no interaction among the factors for nutrient content in coffee leaves, but there was a significant inoculation effect for all nutrients and a significant B. pilosa competition effect for $\mathrm{P}$ and $\mathrm{Fe}$ contents.

Height, leaf area, root and leaf dry mass and number of reproductive branches in the coffee plants were negatively affected by the competition with $B$. pilosa, but this effect was dependent on the inoculation with AMF. The stem dry weight was also reduced, however, independently of inoculation (Table 2).

Table 2. Growth parameters and mass accumulation by Coffea arabica (Catuaí Vermelho IAC 99 cultivar), according to the inoculation with mycorrhizal fungi and competition with Bidens pilosa seedlings, for 120 days.

\begin{tabular}{|c|c|c|c|c|c|c|}
\hline \multirow{3}{*}{ Coffee plant } & \multicolumn{6}{|c|}{ Bidens pilosa } \\
\hline & Absent & Present & Absent & Present & Absent & Present \\
\hline & \multicolumn{2}{|c|}{ Height $(\mathrm{cm})$} & \multicolumn{2}{|c|}{ Leaf area $\left(\mathrm{m}^{2}\right)$} & \multicolumn{2}{|c|}{ Root dry mass (g) } \\
\hline Non-inoculated & $37.0 \mathrm{bA}^{1}$ & $22.9 \mathrm{bB}$ & $0.21 \mathrm{bA}$ & $0.08 \mathrm{bB}$ & $10.8 \mathrm{bA}$ & $7.5 \mathrm{bB}$ \\
\hline Claroideoglomus etunicatum & $41.1 \mathrm{aA}$ & $31.2 \mathrm{aB}$ & $0.28 \mathrm{aA}$ & $0.12 \mathrm{aB}$ & $12.9 \mathrm{aA}$ & $11.4 \mathrm{aB}$ \\
\hline Dentiscutata heterogama & $42.1 \mathrm{aA}$ & $31.8 \mathrm{aB}$ & $0.25 \mathrm{aA}$ & $0.11 \mathrm{aB}$ & $13.2 \mathrm{aA}$ & $11.5 \mathrm{aB}$ \\
\hline Average & 40.1 & 28.6 & 0.25 & 0.10 & 12.3 & 10.1 \\
\hline \multirow[t]{2}{*}{ CV (\%) } & \multicolumn{2}{|c|}{8.3} & \multicolumn{2}{|c|}{7.4} & \multicolumn{2}{|c|}{8.6} \\
\hline & \multicolumn{2}{|c|}{ Leaf dry mass $(\mathrm{g})$} & \multicolumn{2}{|c|}{ Stem dry mass $(\mathrm{g})$} & \multicolumn{2}{|c|}{ Number of plagiotropic branches } \\
\hline Non-inoculated & $16.9 \mathrm{~A}$ & $9.3 \mathrm{~B}$ & 8.5 & 7.3 & $6.5 \mathrm{bA}$ & $4.3 \mathrm{bB}$ \\
\hline Claroideoglomus etunicatum & $18.7 \mathrm{~A}$ & $9.5 \mathrm{~B}$ & 9.5 & 8,2 & $9.3 \mathrm{aA}$ & $5.0 \mathrm{aB}$ \\
\hline Dentiscutata heterogama & $18.3 \mathrm{~A}$ & $9.4 \mathrm{~B}$ & 9.4 & 8.0 & $8.0 \mathrm{abA}$ & $4.3 \mathrm{abB}$ \\
\hline Average & $18.0 \mathrm{~A}$ & $9.4 \mathrm{~B}$ & $9.1 \mathrm{~A}$ & $7.9 \mathrm{~B}$ & 7.9 & 4.5 \\
\hline CV (\%) & \multicolumn{2}{|c|}{11.2} & \multicolumn{2}{|c|}{16.2} & \multicolumn{2}{|c|}{20.1} \\
\hline
\end{tabular}


Inoculation reduced the harmful effect of the weed for height, leaf area and root dry mass. Coffee plants under the interference of $B$. pilosa and not inoculated were reduced by $38 \%$ for height, $60 \%$ for leaf area and $45 \%$ for root dry mass. These values, when the plants were inoculated, were $24 \%$ for height, $57 \%$ for leaf area and $12 \%$ for root dry weight (Table 2).

The coffee growth reduction was due to the competition with $B$. pilosa, because it has a higher use efficiency of water, light and nutrients. B. pilosa is known for its efficient root system, and also as one of the most important weeds in the world (Santos \& Cury 2011). Its higher initial growth promotes the decrease in coffee seedlings growth in the field (Ronchi \& Silva 2006). However, given the inoculation of coffee seedlings with AMF spores, the crop was more competitive and had minor damages caused by B. pilosa. This may be due to the beneficial effect of symbiosis in increasing the growth of the crop root system and thus absorption of water and nutrients (Ferrazzano \& Williamson 2013).

The inoculation of the two fungi promoted the highest growth of coffee plants, especially when there was no interference of $B$. pilosa. Inoculated with AMF (independently of the species) and in competition, the coffee plants had an increase in height (12\%), leaf area (24\%) and root dry mass $(21 \%)$. When the plants were grown without weed interference, the increases were $38 \%$ for height, $32 \%$ for leaf area and $53 \%$ for root dry mass. The number of plagiotropic branches was affected only by the $C$. etunicatum inoculation, wherein the values increased by $43 \%$ when the coffee plants were grown without competition and $16 \%$ under competition (Table 2).

The C. etunicatum inoculum produced more plagiotropic branches, when compared to the D. heterogama inoculation (Table 2). It is known that there is a great diversity of the AMF that enhance the growth of coffee plants, but the species are influenced by environmental factors, particularly edaphic ones (Bainard et al. 2011, Trejo et al. 2011). In this study, the advantage provided by C. etunicatum was probably due to its absolute establishment, evidenced by the highest percentage of root colonization (Table 3).

The percentage of coffee root length colonized was reduced by the competition with $B$. pilosa, and was different among AMF fungi. Colonization by
D. heterogama was 2.9 times higher, when compared to non-inoculated plants, and colonization by C. etunicatum was 3.8 times higher. Furthermore, in non-inoculated coffee plants, the interference of B. pilosa reduced the percentage of root colonization by $36 \%$. On the other hand, the seedlings inoculated with $D$. heterogama reduced colonization by $20 \%$ with the B. pilosa interference, while the inoculation with $C$. etunicatum reduced colonization by $27 \%$ (Table 3).

The highest colonization percentage of coffee plants inoculated with $C$. etunicatum may be related to the colonizing system of this fungus. C. etunicatum is known for its root colonization using spores, hyphae or other propagules. On the other hand, species from the Gigasporaceae family, such as D. heterogama, only do it via spores (Morton 1990, Smith \& Smith 2012).

Coffee plants have mycorrhizal colonization increased by living with two plants. However, this is dependent on fungal colonization (Cardoso et al. 2003), as well as by the interference of other plants, due to lower development of the root system or impaired nutritional balance (Trejo et al. 2011). This fact may be related to the lower percentage of colonization in roots under interference.

The coffee seedling production phase, as well as the first year of cultivation in the field, is extremely important for a sustainable crop establishment, mainly due to its slow initial growth. At this stage, plants are more sensitive to weed interference, and are affected by poorly managed consortia, when other plants can cause shading and reduce the access to nutrients and water (Damatta 2004). For this reason, the AMF inoculation provides a better development of coffee plants, because the association can improve

Table 3. Percentage of root length colonized by mycorrhizal fungi in coffee seedlings (Catuaí Vermelho IAC 99 cultivar) under inoculation and Bidens pilosa competition treatments.

\begin{tabular}{|c|c|c|c|}
\hline \multirow{2}{*}{ Coffee Plant } & \multicolumn{2}{|c|}{ Bidens pilosa } & \multirow{2}{*}{ Average } \\
\hline & Absent & Present & \\
\hline Non-inoculated & $12.9 \mathrm{~A}^{1}$ & $8.2 \mathrm{~B}$ & $10.6 \mathrm{c}$ \\
\hline Claroideoglomus etunicatum & $45.6 \mathrm{~A}$ & $33.4 \mathrm{~B}$ & $39.8 \mathrm{a}$ \\
\hline Dentiscutata heterogama & $34.7 \mathrm{~A}$ & $27.8 \mathrm{~B}$ & $31.3 \mathrm{~b}$ \\
\hline Average & $31.1 \mathrm{~A}$ & $23.3 \mathrm{~B}$ & \\
\hline
\end{tabular}

$\frac{\mathrm{CV}(\%)}{{ }^{1} \text { Averages followed by the same capital letter in the line do not differ by the F test, }}$ and averages followed by the same lowercase letter in the column do not differ by the Tukey test $(\mathrm{p}<0.05)$. 
the soil exploration area, and therefore a greater absorption of water and nutrients. Thus, despite the reduced growth of the coffee plants caused by the competition with $B$. pilosa, the inoculation with AMF reduces the negative effects caused by the interference (Figure 1).

The inoculation of coffee plants with C. etunicatum or D. heterogama reduced the shoot dry mass of $B$. pilosa by $55 \%$ and the root dry mass by $26 \%$ (Table 4 ). This is due to the better growth rate of inoculated coffee plants (Table 2). Coexisting plants compete for resources, and this competition is detrimental to both species. Under coexistence, plants with higher growth rate have the ability to suppress the development and outcompete the plants surroundings (Knezevic \& Datta 2015).

After the foliar analysis of coffee seedlings, regarding nutrient contents, it was observed that the concentrations of $\mathrm{P}, \mathrm{K}, \mathrm{Ca}, \mathrm{Cu}, \mathrm{Fe}$ and $\mathrm{Zn}$ were higher in inoculated plants, when compared to the noninoculated ones. Moreover, among such nutrients,

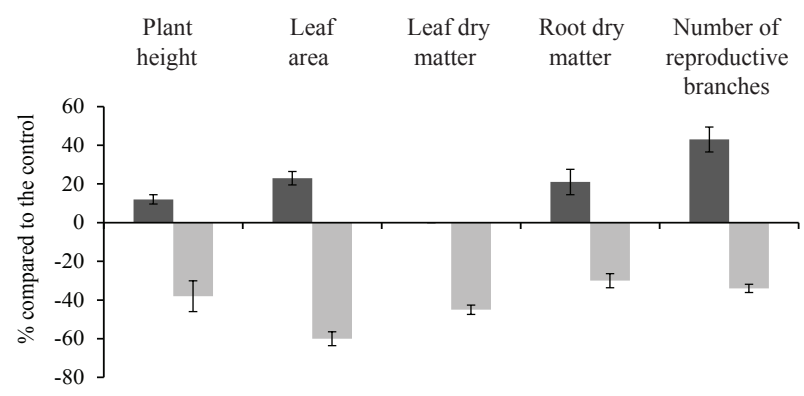

Figure 1. Positive effects caused by inoculating Dentiscutata heterogama and Claroideoglomus etunicatum (dark grey bars) and negative effects caused by competition with Bidens pilosa (light grey bars), in Coffea arabica seedlings. * Averages were significantly different at $5 \%$, by the $\mathrm{F}$ test. Standard errors are presented at the end of the bars.

Table 4. Dry mass of Bidens pilosa after 120 days of competition with coffee plants inoculated or not with mycorrhizal fungi.

\begin{tabular}{llc}
\hline \multirow{2}{*}{ Coffee plant } & \multicolumn{2}{c}{ Dry mass $\left(\mathrm{g}\right.$ plant $\left.{ }^{-1}\right)$} \\
\cline { 2 - 3 } & Shoot & Root \\
\hline Non-inoculated & $25.2 \mathrm{a}^{1}$ & $9.3 \mathrm{a}$ \\
Claroideoglomus etunicatum & $11.0 \mathrm{~b}$ & $6.6 \mathrm{~b}$ \\
Dentiscutata heterogama & $11.8 \mathrm{~b}$ & $7.3 \mathrm{~b}$ \\
\hline CV $(\%)$ & 16.2 & 16.3 \\
\hline
\end{tabular}

${ }^{1}$ Averages followed by the same letter in the column do not differ by the Tukey test $(\mathrm{p}<0.05)$. only the $\mathrm{Zn}$ content was affected by the inoculated fungal species. In the coffee plants leaves, $\mathrm{Mg}$ and Mn were not influenced by the competition with B. pilosa or by inoculation with AMF (Table 5).

One of the advantages of the direct association with mycorrhizal fungi is the greater absorption of nutrients, primarily those of low solubility, and when it comes to low fertility areas, such as the soil used in this study (Table 1). In addition, the gain obtained with AMF may be most evident in areas under management with low investment in technology (Trejo et al. 2011), which often leads to low fertility soils.

Regarding the $\mathrm{P}$ content in coffee leaves, it was observed that inoculated plants have an average of $2.5 \mathrm{~g} \mathrm{~kg}^{-1}$, while non-inoculated plants showed $1.5 \mathrm{~g} \mathrm{~kg}^{-1}$. In other words, the AMF inoculation caused an increase of $67 \%$ in the accumulation of P. In the same way, the plants under B. pilosa interference suffered a reduction of $75 \%$ in foliar $P$ content (Table 5).

The mycorrhizal colonization is primarily related to higher P uptake by plants. According to Smith \& Smith (2012), the nutrient uptake by inoculated plants can exceed $50 \%$, when plants are grown in low fertility soil, if compared to the noninoculated ones. The $\mathrm{P}$ accumulation and biomass gain are positive and exponentially related to the root colonization rate by fungi. In this sense, Hoeksema et al. (2010) demonstrated that plants inoculated with AMF can increase their biomass by 3.1 times more than uncolonized plants.

The $\mathrm{K}$ content in the leaves was not influenced by the competition with B. pilosa. However, AMF inoculation doubled the concentration of this element in coffee leaves. Likewise, $\mathrm{Ca}$ and $\mathrm{Cu}$ concentrations were elevated by $39 \%$ and $52 \%$, respectively, with AMF inoculation (Table 5).

Regarding the micronutrient $\mathrm{Fe}$, it was observed that the interference of $B$. pilosa caused an average reduction of $15 \%$ in its concentration only under AMF inoculation. In addition, independently of weed interference, AMF caused an increase of $19 \%$ in the Fe content. It was also observed that the inoculation of $C$. etunicatum promoted an increment of $38 \%$ of $\mathrm{Zn}$ on coffee leaves. However, there was no interference of $B$. pilosa on this nutrient (Table 5).

The $B$. pilosa interference on micronutrients accumulation by crops is less important, when 
compared to the macronutrients assimilation. This is because the critical levels of micronutrients for this weed are low (Santos \& Cury 2011). For coffee seedlings, the critical levels of $\mathrm{Zn}$ and Fe are respectively $3.68-4.08 \mathrm{mg} \mathrm{kg}^{-1}$ and $209-214 \mathrm{mg}$ $\mathrm{kg}^{-1}$ (Gontijo et al. 2007). The $\mathrm{Zn}$ content provided is above the critical range for coffee plants. On the other hand, the Fe content is below, what may explain the improvements in coffee seedlings nutrition after AMF inoculation.
It was observed in this study that the process of inoculation was effective to raise the $\mathrm{K}$ content values from $\sim 10 \mathrm{~g} \mathrm{~kg}^{-1}$ to more than $20 \mathrm{~g} \mathrm{~kg}^{-1}$, which are greater than the critical value for the production of seedlings in this development stage (Clemente et al. 2008). Moreover, AMF inoculation was beneficial to the accumulation of most nutrients $(\mathrm{P}$, $\mathrm{K}, \mathrm{Ca}, \mathrm{Cu}$ and $\mathrm{Zn}$ ), what goes toward sustainable coffee production, especially considering the high fertilization cost.

Table 5. Nutrient levels in coffee plants (Catuaí Vermelho IAC 99 cultivar) leaves, according to the inoculation with mycorrhizal fungi and competition with Bidens pilosa.

\begin{tabular}{|c|c|c|c|c|c|c|}
\hline \multirow{3}{*}{ Fungi } & \multicolumn{6}{|c|}{ Bidens pilosa } \\
\hline & Absent & Present & \multirow{2}{*}{ Average } & Absent & Present & \multirow{2}{*}{ Average } \\
\hline & \multicolumn{2}{|c|}{$\mathrm{P}\left(\mathrm{g} \mathrm{kg}^{-1}\right)$} & & \multicolumn{2}{|c|}{$\mathrm{K}\left(\mathrm{g} \mathrm{kg}^{-1}\right)$} & \\
\hline Non-inoculated & 1.7 & 1.2 & $1.5 \mathrm{~b}$ & 11.2 & 9.9 & $10.6 b^{1}$ \\
\hline Claroideoglomus etunicatum & 2.9 & 2.1 & $2.5 \mathrm{a}$ & 21.5 & 19.2 & $20.3 \mathrm{a}$ \\
\hline Dentiscutata heterogama & 2.7 & 2.1 & $2.4 \mathrm{a}$ & 24.8 & 18.7 & $21.7 \mathrm{a}$ \\
\hline Average & $2.4 \mathrm{~A}$ & $1.8 \mathrm{~B}$ & & 1.2 & 15.9 & \\
\hline \multirow[t]{2}{*}{ CV (\%) } & & 9.9 & & & 33.6 & \\
\hline & \multicolumn{2}{|c|}{$\mathrm{Ca}\left(\mathrm{g} \mathrm{kg}^{-1}\right)$} & Average & \multicolumn{2}{|c|}{$\operatorname{Mg}\left(\mathrm{g} \mathrm{kg}^{-1}\right)$} & Average \\
\hline Non-inoculated & 1.1 & 1.2 & $1.2 \mathrm{~b}$ & 0.24 & 0.23 & 0.24 \\
\hline Dentiscutata heterogama & 1.8 & 1.5 & $1.7 \mathrm{a}$ & 0.21 & 0.16 & 0.19 \\
\hline Claroideoglomus etunicatum & 1.4 & 1.7 & $1.5 \mathrm{a}$ & 0.24 & 0.24 & 0.25 \\
\hline Average & 1.4 & 1.5 & & 0.23 & 0.21 & \\
\hline \multirow[t]{2}{*}{$\mathrm{CV}(\%)$} & & 18.2 & & & 39.7 & \\
\hline & \multicolumn{2}{|c|}{$\mathrm{Cu}\left(\mathrm{mg} \mathrm{kg}^{-1}\right)$} & Average & \multicolumn{2}{|c|}{$\mathrm{Fe}\left(\mathrm{mg} \mathrm{kg}^{-1}\right)$} & Average \\
\hline Non-inoculated & 8.1 & 6.9 & $7.5 \mathrm{~b}$ & $59.4 \mathrm{~A}$ & $58.8 \mathrm{~A}$ & $59.1 \mathrm{~b}$ \\
\hline Dentiscutata heterogama & 11.3 & 11.9 & $11.6 \mathrm{a}$ & $74.5 \mathrm{~A}$ & $64.1 \mathrm{~B}$ & $69.2 \mathrm{a}$ \\
\hline Claroideoglomus etunicatum & 11.1 & 11.4 & $11.3 \mathrm{a}$ & $77.4 \mathrm{~A}$ & $65.2 \mathrm{~B}$ & $71.3 \mathrm{a}$ \\
\hline Average & 10.2 & 10.1 & & $70.4 \mathrm{~A}$ & $62.7 \mathrm{~B}$ & \\
\hline \multirow[t]{2}{*}{ CV $(\%)$} & & 8.1 & & & 10.2 & \\
\hline & \multicolumn{2}{|c|}{$\mathrm{Mn}\left(\mathrm{mg} \mathrm{kg}^{-1}\right)$} & Average & \multicolumn{2}{|c|}{$\mathrm{Zn}\left(\mathrm{mg} \mathrm{kg}^{-1}\right)$} & Average \\
\hline Non-inoculated & 60.6 & 59.2 & $59.9 \mathrm{a}$ & 4.8 & 4.5 & $4.7 \mathrm{~b}$ \\
\hline Claroideoglomus etunicatum & 59.4 & 66.3 & $62.8 \mathrm{a}$ & 6.6 & 6.3 & $6.4 \mathrm{a}$ \\
\hline Dentiscutata heterogama & 60.1 & 57.9 & $58.9 \mathrm{a}$ & 5.8 & 5.7 & $5.8 \mathrm{ab}$ \\
\hline Average & 60.0 & 61.1 & & 5.7 & 5.5 & \\
\hline $\mathrm{CV}(\%)$ & & 14.9 & & & 19.4 & \\
\hline
\end{tabular}

Table 6. Nutrient contents in Bidens pilosa leaves after 120 days in competition with coffee seedlings inoculated with mycorrhizal fungi.

\begin{tabular}{|c|c|c|c|c|c|c|c|c|}
\hline \multirow{3}{*}{ Coffee seedling } & \multicolumn{8}{|c|}{ Nutrient } \\
\hline & $\mathrm{P}$ & $\mathrm{K}$ & $\mathrm{Ca}$ & $\mathrm{Mg}$ & $\mathrm{Fe}$ & $\mathrm{Cu}$ & $\mathrm{Mn}$ & $\mathrm{Zn}$ \\
\hline & \multicolumn{4}{|c|}{$\mathrm{g} \mathrm{kg}^{-1}$} & \multicolumn{4}{|c|}{$\mathrm{mg} \mathrm{kg}^{-1}$} \\
\hline Non-inoculated & $4.0 \mathrm{a}^{1}$ & $33.5 \mathrm{a}$ & $0.91 \mathrm{a}$ & $0.21 \mathrm{a}$ & $11.4 \mathrm{a}$ & $78.2 \mathrm{a}$ & $27.3 \mathrm{a}$ & $11.5 \mathrm{a}$ \\
\hline Claroideoglomus etunicatum & $3.6 \mathrm{a}$ & $30.1 \mathrm{a}$ & $1.13 \mathrm{a}$ & $0.28 \mathrm{a}$ & $11.2 \mathrm{a}$ & $80.3 \mathrm{a}$ & $28.3 \mathrm{a}$ & $14.3 \mathrm{a}$ \\
\hline Dentiscutata heterogama & $3.6 \mathrm{a}$ & $27.9 \mathrm{a}$ & $1.14 \mathrm{a}$ & $0.22 \mathrm{a}$ & $11.3 \mathrm{a}$ & $87.1 \mathrm{a}$ & $27.8 \mathrm{a}$ & $15.3 \mathrm{a}$ \\
\hline $\mathrm{CV}(\%)$ & 16.9 & 21.8 & 64.1 & 57.5 & 1.6 & 11.7 & 37.7 & 14.3 \\
\hline
\end{tabular}

${ }^{1}$ Averages followed by the same letter in the column do not differ by the Tukey test $(\mathrm{p}<0.05)$. 
The best growth of coffee plants did not affect the nutrient content in leaves of B. pilosa (Table 6). Santos \& Cury (2011) emphasize that $B$. pilosa plants have high phenotypic plasticity. Even under adverse growing conditions, $B$. pilosa is efficient in assimilating the environmental resources and complete the cycle. The non-interference of inoculated coffee plants on the foliar nutrient content of $B$. pilosa is an indication of its high competitiveness power.

\section{CONCLUSIONS}

1. The inoculation of Claroideoglomus etunicatum and Dentiscutata heterogama in Arabica coffee seedlings increases the competitive power of the crop against the Bidens pilosa interference.

2. The inoculation of Claroideoglomus etunicatum and Heterogama Dentiscutata increases growth, dry matter accumulation and leaf contents of $\mathrm{P}, \mathrm{K}$, $\mathrm{Ca}, \mathrm{Cu}, \mathrm{Fe}$ and $\mathrm{Zn}$, in coffee seedlings.

3. The artificial inoculation in coffee seedlings with mycorrhizal fungi indirectly decreases the dry matter accumulation by Bidens pilosa .

\section{ACKNOWLEDGMENTS}

The authors are grateful to the Fundação de Amparo à Pesquisa do Estado de Minas Gerais (Fapemig), Coordenação de Aperfeiçoamento de Pessoal de Nível Superior (Capes) and Conselho Nacional de Desenvolvimento Científico e Tecnológico (CNPq), for the support on the realization and publication of this paper, and to the Coleção Internacional de Culturas de Glomeromycota (CICG), for donating the fungi inoculum.

\section{REFERENCES}

ANTUNES, W. C. et al. Allometric models for nondestructive leaf area estimation in coffee (Coffea arabica and Coffea canephora). Annals of Applied Biology, v. 59, n. 1, p. 1-8, 2008.

ASSOCIATION OF OFFICIAL ANALYTICAL CHEMISTS (AOAC). Official methods of analysis. 12. ed. Washington, DC: AOAC, 1975.

BAINARD, L. D. et al. Mycorrhizal fungi in tree-based intercropping systems: a review of their abundance and diversity. Pedobiologia, v. 54, n. 2, p. 57-61, 2011.
BRAGA, J. M.; DE FELLIPO, B. V. Determinação espectrofotométrica de fósforo em extratos de solos e plantas. Revista Ceres, v. 21, n. 2, p. 73-85, 1974.

CARDOSO, I. M. et al. Distribution of mycorrhizal fungal spores in soils under agroforestry and monocultural coffee systems. Agroforestry Systems, v. 58, n. 1, p. 33-43, 2003.

CARVAlHo, F. P. et al. Sensibilidade de plantas de café micorrizadas a herbicidas. Revista Brasileira de Herbicidas, v. 13, n. 2, p. 134-142, 2014.

CLEMENTE, F. M. V. et al. Faixas críticas de teores foliares de macronutrientes no cafeeiro em pós-plantio: primeiro ano. Coffee Science, v. 3, n. 1, p. 47-57, 2008.

DAMATTA, F. M. Ecophysiological constraints on the production of shaded and unshaded coffee: a review. Field Crops Research, v. 86, n. 1, p. 99-114, 2004.

FERRAZZANO, S.; WILLIAMSON, P. S. Benefits of mycorrhizal inoculation in reintroduction of endangered plant species under drought conditions. Journal of Arid Environments, v. 98, n. 1, p. 123-125, 2013.

FRANÇA, A. C. et al. Crescimento de mudas de cafeeiro inoculadas com fungos micorrízicos arbusculares. Revista Brasileira de Ciências Agrárias, v. 9, n. 4, p. 506-511, 2014.

GERDEMANN, J. W.; NICHOLSON, T. H. Spores of mycorrhizal Endogone extracted from soil by wet sieving and decanting. Transactions of the British Mycological Society, v. 46, n. 2, p. 235-244, 1963.

GIOVANNETTI, M.; MOSSE, B. An evaluation of techniques for measuring arbuscular mycorrhizal infection in roots. New Phytologist, v. 84, n. 1, p. 489-500, 1980.

GONTIJO, R. A. N. et al. Faixas críticas de teores foliares de micronutrientes em mudas de cafeeiro (Coffea arabica L.). Coffee Science, v. 2, n. 2, p. 135-141, 2007.

HARKER, K. N.; O'DONOVAN, J. T. Recent weed control, weed management, and integrated weed management. Weed Technology, v. 27, n. 1, p. 1-11, 2013.

HOEKSEMA J. D. et al. A meta-analysis of contextdependency in plant response to inoculation with mycorrhizal fungi. Ecology Letters, v. 13, n. 2, p. 394407, 2010.

KNEZEVIC, S. Z.; DATTA, A. The critical period for weed control: revisiting data analysis. Weed Science, v. 63, special n., p. 188-202, 2015.

MORTON, J. B. Revised classification of arbuscular mycorrhizal fungi (Zygomycetes): a new order Glomales, two new suborders Glomineae and Gigasporineae and two new families Acaulosporaceae and Gigasporaceae with 
an emendation of Glomaceae. Mycotaxon, v. 37, n. 1, p. 471-491, 1990.

OERKE, E. C. Centenary review: crop losses to pests. Journal of Agricultural Science, v. 144, n. 2, p. 31-43, 2006.

PAGANO, M. C.; CABELlO, M. N.; SCOTTI, M. R. Arbuscular mycorrhizal colonization and growth of Eremanthus incanus Less. in a highland field. Plant, Soil and Environment, v. 56, n. 9, p. 412-418, 2010.

RINAUDO, V. et al. Mycorrhizal fungi suppress aggressive agricultural weeds. Plant and Soil, v. 333, n. 1, p. 7-20, 2010.

RONCHI, C. P. et al. Growth and nutrient concentration in coffee root system under weed species competition. Planta Daninha, v. 25, n. 4, p. 679-687, 2007.
RONCHI, C. P.; SILVA. A. A. Effects of weed species competition on the growth of young coffee plants. Planta Daninha, v. 24, n. 3, p. 415-423, 2006.

SANTOS, J. B.; CURY, J. P. Picão-preto: uma planta daninha especial em solos tropicais. Planta Daninha, v. 29, special n., p. 1159-1171, 2011.

SMITH, S. E.; SMITH, F. A. Fresh perspectives on the roles of arbuscular mycorrhizal fungi in plant nutrition and growth. Mycologia, v. 104, n. 1, p. 1-13, 2012.

TREJO, D. et al. Efectividad de siete consorcios nativos de hongos micorrízicos arbusculares en plantas de café en condiciones de invernadero y campo. Revista Chilena de Historia Natural, v. 84, n. 1, p. 23-31, 2011.

VEIGA, R. S. L. et al. Can arbuscular mycorrhizal fungi reduce the growth of agricultural weeds? Plos One, v. 6, n. 12, p. 1-10, 2011. 